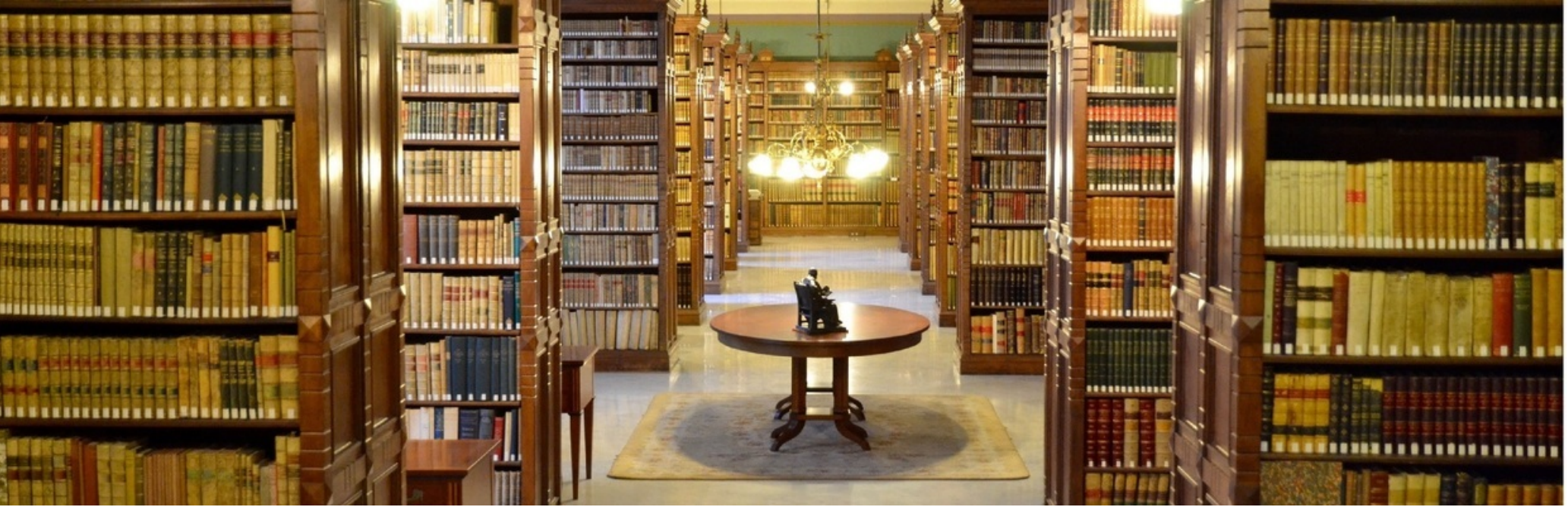

\title{
Editorial Volume 9, Issue 1
}

Authors: $\quad$ Stephan Seiler

Submitted: $\quad$ 7. March 2022

Published: $\quad$ 7. March 2022

Volume: $\quad 9$

Issue: $\quad 1$

Affiliation: $\quad$ IASHA / JOSHA Journal. Freiburg, Germany

Languages: English

Keywords: $\quad$ Editorial, JOSHA Journal, 2022 Volume 9, Issue 1

Categories: News and Views

DOI: $\quad 10.17160 /$ josha.9.1.807

Abstract:

Dear josha-journal readers, While we were still thinking mainly about Corona when we wrote the last editorial and wished our readers a happy new year 2022, we are thrown back on the hard ground of facts only two months later. There is a war going on in Europe, an unimaginable event for all of us! Especially the Josha team, which since its foundation has always been committed to international friendship and cooperation across all territorial borders, is horrified. Our contributor Silke therefore dedicates an article to the attacked country of Ukraine with its anthem and the context of its creation. We will not be stopped in our quest to make science and art accessible to all and wish all readers a successful read despite the dramatic events. 


\section{Editorial}

Volume 9 , Issue 1

\section{What will happen next?}

Dear josha-journal readers,

While we were still thinking mainly about Corona when we wrote the last editorial and wished our readers a happy new year 2022, we are thrown back on the hard ground of facts only two months later. There is a war going on in Europe, an unimaginable event for all of us! Especially the Josha team, which since its foundation has always been committed to international friendship and cooperation across all territorial borders, is horrified. Our contributor Silke therefore dedicates an article to the attacked country of Ukraine with its anthem and the context of its creation. We will not be stopped in our quest to make science and art accessible to all and wish all readers a successful read despite the dramatic events.

\section{Dr. Stephan Seiler \\ Vice President}

International Academy of Sciences, Humanities and Arts

Volume 9 , Issue 2

Robert M. Kaplan: Murder by Death: Renfield Syndrome

Julieta Alcain: Of Mice and Humans

Ignacio Mastroleo: Philosophy Research Program on Artificial Intelligence and Machine Learning in Oncology

Sewanou Lanmadousselo: The Problem of the Authenticity of african Fairy Tales using the examples of the Fairy Tales of the Fon from Benin and the "Kinder- und Hausmärchen" of the Brothers Grimm Joachim-Friedrich Kapp: Auszüge aus dem Buch „Der Mensch Jesus und der ungläubige Christ“

Robert M. Kaplan: Das doppelgänger Freud. A review of Freud's Patients: A Book of Lives

Julieta Alcain, Nicolas Chiarante, Matías Zelaya: La máquina de hacer pastillas - The pill-making machine

Silke Masullo: „United We Stand with the People of the Ukraine" 